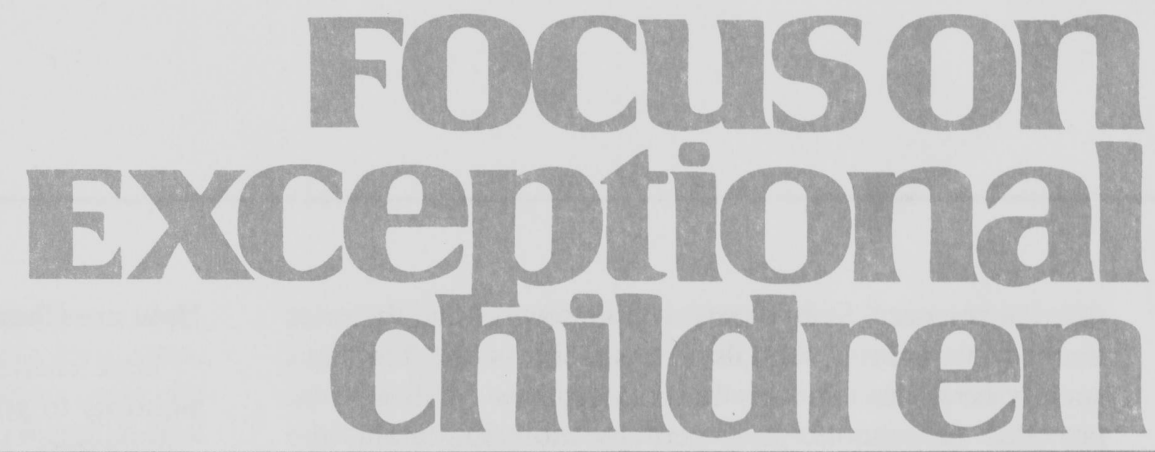

\title{
Students with Disabilities in Charter Schools: What We Now Know
}

\author{
Lauren Morando Rhim and Margaret McLaughlin
}

School choice is a key feature of the educational reforms that have evolved over the past two decades. It is one of the "market reforms" that were introduced in the late 1980s as part of a broader effort to improve educational outcomes and productivity. School choice can take several forms, such as vouchers or opportunity scholarships, magnet schools, and the focus of this article - charter schools. All of these options are designed to infuse private-sector market forces-specifically, autonomy, competition, and choiceinto public education (Chubb \& Moe, 1990).

This article provides an overview of the charter school movement in the United States and a synthesis of the findings of the studies that have been conducted for nearly a decade by the University of Maryland in collaboration with the National Association of State Directors of Special Education (NASDSE). The research documents the evolution of charter schools from a somewhat radical reform initiative in a single state to an established program that now exists in 40 states and the District of Columbia. This research focuses specifically on how charter schools have served students with disabilities and the policy issues involved in providing special education in charter schools.

The charter school discussion is attended by a great deal of controversy and misunderstanding. For instance, many are not aware that charter schools are public schools or realize that these schools must comply with most of the same federal laws and regulations as traditional public schools. Given that the conversion to charter schools is one of the options specified under the No Child Left Behind Act of 2001 (NCLB) for failing schools, we must understand the way these schools operate and the issues emerging in regard to educating students with disabilities in this new sector of education.

\section{AN OVERVIEW OF CHARTER SCHOOLS}

Charter schools are publicly funded autonomous schools that operate under a contract that specifies the characteristics of the educational program that will be offered (e.g., core knowledge curriculum, multi-age ungraded) and the population of students that will be served (e.g., students living in a specific neighborhood, students interested

\footnotetext{
Lauren Morando Rhim is a Senior Consultant for Public Impact, Chapel Hill, NC, and Margaret J. McLaughlin is a Professor of Special Education at the University of Maryland, College of Education. Funding for the research studies described here was provided by the U.S. Department of Education. Opinions expressed in this article are those of the authors and do not necessarily reflect the views of the U.S. Department of Education. For more information about the project, see http://www.education.umd.edu/EDSP/ProjectIntersect/index.html.
} 
in art or science). State charter school laws define the rules that govern charter schools in a specific state. The laws specify how charters may be granted, how funds will be provided to schools, and, perhaps most important, the extent of autonomy extended to the schools. State laws also specify whether each individual charter school is also its own local district or whether the school is part of a local school district.

The first charter school law was passed in Minnesota in 1991. Since then, 40 states and the District of Columbia have passed charter school legislation. As of the fall of 2006, approximately 1.1 million students were enrolled in 3,943 charter schools across the country (Center for Education Reform, 2007). The U.S. Department of Education (USDE) created the Public Charter School Program (PCSP) in 1995 to assist states, districts, and charter founding groups to open charter schools (Finnigan et al., 2004). The federal government has assumed a relatively proactive role, awarding nearly \$215 million dollars in grants in 2006 to states and individual charter schools to support the planning, development, and initial implementation of charter schools (USDE, 2007).

\section{FOCuson
Exceptional
children}

ISSN 0015-511X FOCUS ON EXCEPTIONAL CHILDREN (USPS 203-360) is published monthly except June, July, and August as a service to teachers, special educators, curriculum specialists, administrators, and those concerned with the special education of exceptional children. This publication is annotated and indexed by the ERIC Clearinghouse on Handicapped and Gifted Children for publication in the monthly Current Index to Journals in Education (CIJE) and the quarterly index, Exceptional Children Education Resources (ECER). The full text of Focus on Exceptional Children is also available in the electronic versions of the Education Index. It is also available in microfilm from Serials Acquisitions, National Archive Publishing Company, P.O. Box 998, Ann Arbor, MI 48106-0998. Subscription rates: individual, \$42 per year; institutions, \$56 per year. Copyright (C) 2007, Love Publishing Company. All rights reserved. Reproduction in whole or part without written permission is prohibited. Printed in the United States of America. Periodical postage is paid at Denver, Colorado. POSTMASTER: Send address changes to:

Love Publishing Company

Executive and Editorial Office P.O. Box 22353

Denver, Colorado 80222

Telephone (303) 221-7333

\section{EDITORIAL BOARD}

Lisa Dieker

University of Central Florida
Paula Maccini University of Maryland

Marleen Pugach

University of Wisconsin-Milwaukee

Carrie E. Watterson Editor
Stanley F. Love

Publisher

\section{How are Charter Schools Created?}

State charter laws define which organizations have the authority to grant charters. These entities are referred to as "authorizers" or "sponsors." A charter authorizer is responsible for reviewing and approving applications from individuals or groups seeking to operate a charter school. In addition, authorizers are the agents responsible for holding charter schools accountable for the goals and objectives articulated in their charter (Sugarman \& Kuboyama, 2001). Local education agencies (LEAs) are the most common type of authorizer, but, in a number of states, state education agencies (SEAs), colleges and universities, special chartering boards, and non-profit organizations are also designated authorizers (Ahearn, Rhim, Lange, \& McLaughlin, 2005; Rhim, Lange, Ahearn, \& McLaughlin, 2007a).

Most authorizers have responsibilities beyond granting charters to schools. Actually, for most, charter-authorizing is a minor role. Exceptions are the chartering boards that have been created specifically to authorize charter schools. Currently, there are only five such boards: The Arizona State Board of Charter Schools, the District of Columbia Public Charter School Board, the Colorado State Charter School Institute, the Idaho Charter School Commission, and the Utah State Charter School Board (Smith, 2005). Although the most common charter school authorizers are local school districts, district authorizers on average have granted only three charters each. In contrast, other authorizers (e.g., charter boards, colleges and universities, state departments of education) have granted an average of 24 charters each (Rhim, Lange, Ahearn \& McLaughlin, 2007a).

Individuals or groups are typically granted a charter to develop and operate a school through a process that entails a review of the applicants' qualifications and an examination of the strength of the academic program proposed (National Association of Charter School Authorizers, 2005; Palmer \& Gau, 2003; Sugarman \& Kuboyama, 2001). In the early years, charter schools were evaluated on the extent to which their programs were "innovative" or unavailable in traditional public schools. Each school's charter specifies the goals that must be met, such as achievement gains. Charters are typically granted for a limited time, usually 3-5 years, and the schools must demonstrate progress toward meeting the goals specified in their charter or risk the revocation or non-renewal of their charters.

\section{Characteristics of Charter Schools}

The core principles underlying charter schools are autonomy and choice. The belief is that freedom from regulation coupled with the market-driven accountability associated with parental choice will lead to more innovative and effective learning environments (Finn, Manno, \& Vanourek, 2000; Hill, Lake, \& Celio, 2002; Kolderie, 1990; Nathan, 1996). Charter schools, however, are funded by public tax dollars and must be accountable to the public. These schools 
must also have open-enrollment policies. Furthermore, charter schools are subject to all federal and state civil rights laws. Whereas traditional public schools operate under the authority of a school district managed by a central district office and an elected or appointed school board, charter schools operate under a contract between a school's charter board and the authorizer. Charter boards are self-appointed and are typically formed by individuals who are interested in starting a charter school.

Charter schools are extremely heterogeneous. In part, this is a result of the differences among state laws, but it also reflects the original intent of the charter school movement to promote innovation. Charter schools have few similarities, both between and within states (Anderson et al., 2002). For instance, California adopted its charter school law in 1992 and has a large charter sector that encompasses more than 621 schools and hundreds of local districts that function as authorizers. California charter schools offer Afrocentric, arts-based, math and science, and technology-focused instructional programs - to name just a few. Charter schools in California enroll 220,000 students (California Department of Education, 2007a), with school enrollments ranging from 3,903 to fewer than 20 students (California Department of Education, 2007b). More than $20 \%$ of the charter schools in California deliver their instructional program via an independent study or virtual environment in which students do not attend school in a traditional brick-and-mortar building (Rhim, Faukner, \& McLaughlin, 2006).

Maryland passed its charter school law in 2003, and to date 23 schools have opened in that state. During the 200506 academic year, the smallest charter school in Maryland enrolled 62 students and the largest enrolled 495 (Maryland State Department of Education, 2007; Rhim, 2006). Unlike California, the Maryland charter law expressly forbids creating independent study/virtual charter schools (Maryland Public Charter School Act, 2003). The small cohort of Maryland charter schools includes a Montessori school, a science-based program, and a teacher-created "green" school.

The early discussion of charter schools focused heavily on choice and competition and their potential to stimulate innovation. Over time, though, there has been little evidence that charter schools are particularly innovative in terms of using new instructional technologies or "breaking the mold" in organization or curricula (Lubienski, 2004). Rather, the notion of innovation has come to be interpreted as any program that provides students with a broader array of learning opportunities than is available in traditional school districts located in the area of the charter school. Examples of these types of innovation are charter schools that offer Montessori or Waldorf programs, and kindergarten through 8th or 12th grade configurations, including those that are ungraded $\mathrm{K}-3$ or $\mathrm{K}-6$ schools. Others offer their curriculum via electronic means (i.e., cyber, virtual, or online charter schools). Although these types of programs or curricula are neither necessarily innovative nor unique to the charter school sector, these options are not offered through public schools in many districts where those charter schools are formed.

Research documenting the outcomes attributed to charter schools has been heavily contested over the years. Advocates and opponents of charter schools point to a number of indicators, such as parent satisfaction, growth in enrollment, dropout rates, and academic achievement, as evidence of the success or failure of charter schools. Nevertheless, claims about the success of charter schools, in particular achievement gains among charter school students, remain inconclusive (Carnoy, Jacobsen, Mishel, \& Rothstein, 2000; Lake \& Hill, 2006). Although, in theory, market-driven accountability associated with the contract renewal process and parental choice would be an incentive for charter schools to operate high-quality programs or risk losing students and/or their charter, no firm evidence exists that in the aggregate charter schools are doing better or worse than traditional public schools.

\section{IDEA and Charter Schools}

As noted earlier, charter schools are required to adhere to all federal civil rights laws, including the Individuals with Disabilities Education Act (IDEA), Sec. 504 of the Rehabilitation Act, and the Americans with Disabilities Act. The 1997 IDEA amendments addressed charter schools and made clear that children with disabilities who attend public charter schools and their parents retain all rights under IDEA. The 1997 law also noted that when a charter school is its own LEA, it is responsible for ensuring that all requirements of the law are met similar to other LEAs in the state (Giovannetti, Ahearn, \& Lange, 2001).

The 2004 amendments made further reference to charter schools, including the right of the state to designate another (unnamed) entity to be responsible for ensuring implementation of IDEA in cases where a charter school is an independent LEA. Students with disabilities enrolled in charter schools that are part of an LEA must be served in the same manner as the LEA serves students with disabilities in its traditional public schools, including providing special education and related services onsite at the charter school to the same extent to which the LEA provides those services in traditional public schools. The LEA must also provide IDEA funds to charter schools on the same basis as it provides funds to its other public schools.

An additional requirement is charter school representation on state special education advisory panels. Interestingly, special education teachers in charter schools may not have to meet the certification requirements specified in IDEA if their state's charter school law does not require that teachers in charter schools be certified (Ahearn, Giovannetti, Lange, Rhim, \& Warren, 2004).

Provisions in the IDEA statute and related regulations underscore the fact that charter schools are public schools and, therefore, are responsible for educating students with 
disabilities and providing those children and their parents a free and appropriate public education (FAPE) to which they are entitled under IDEA. A key factor in determining both a charter school's responsibility and its accountability under IDEA is whether the school is part of an LEA or its own LEA (Heubert, 1997).

As noted earlier, state charter laws define whether individual charter schools are independent LEAs. In reality, state charter laws permit three variations, sometimes all within a single state. These include (1) making charter schools part of a local education agency, (2) making them part of an independent local district, or (3) determining their legal status at the time they submit their charter application. In 12 states all charter schools are considered to be independent LEAs. In 18 states every charter is considered to be a school within an existing LEA. In 11 states legal status is designated according to who authorizes the school or grants schools the option to elect to be either part of a district or their own district (Ahearn, Rhim, Lange, \& McLaughlin, 2005).

If a charter is part of an LEA, the responsibility for special education is shared between the state and the district. If the charter school is its own LEA, however, it is responsible for all requirements in IDEA that are assigned to a traditional school district. For example, the charter school is responsible for Child Find and implementing all procedures and timelines associated with evaluations as well as developing Individual Education Programs (IEPs) for making available the full continuum of educational settings as defined in the least restrictive environment (LRE) regulations. Needless to say, the requirements of IDEA have created some unique tensions between charter schools and the traditional educational sector. Responsibilities under IDEA can be daunting for new charter operators, and a great deal of mistrust of charter schools can develop among special education administrators in traditional LEAs. In the following discussion we provide some of the key findings from our extensive research of special education and charter schools

\section{RESEARCH ON STUDENTS WITH DISABILITIES IN CHARTER SCHOOLS}

A summary of the research related to key policy tensions and practical challenges associated with educating students with disabilities in the charter sector follows. First we indicate our data sources for this research.

\section{Data Sources}

The first research study, conducted under the auspices of the Center for Disability Policy Research, examined issues related to special education in the emerging charter sector in Colorado, an early adopter of the charter concept (McLaughlin \& Henderson, 1998). The second study, Project SEARCH, was exploratory in nature and described and documented the emerging key policy issues related to special education in charter schools. Project SEARCH entailed a review of charter legislation in 15 states and in-depth case studies in seven states (Arizona, California, Colorado, Connecticut, Florida, Minnesota, and North Carolina) and the District of Columbia (Ahearn, Lange, McLaughlin, \& Rhim, 2001; Rhim \& McLaughlin 2001).

The third research study, Project Intersect, built on the findings from Project SEARCH and sought to quantify the status of special education in charter schools nationwide and thereafter, to document how charter schools are building the capacity to provide special education and related services to students with disabilities through a review of state statutes (Ahearn, Rhim, Lange, \& McLaughlin, 2005); a series of four national surveys (Lange, Rhim, Ahearn, \& McLaughlin, 2005; Rhim, Lange, Ahearn, \& McLaughlin, 2005; 2007a; 2007b); a multi-case study of charter school special education infrastructures (Rhim, Lange, Ahearn, \& McLaughlin, 2006); and an in-depth descriptive analysis of special education enrollment, service provision, and outcomes in California charter schools (Rhim, Faukner, \& McLaughlin, 2006).

The following findings from our research and related research on special education in charter schools are summarized according to four major areas: (1) central policy tensions, (2) practical challenges, and (3) student outcomes.

\section{Central Policy Tensions}

Special education policy, as interpreted at the local school level, represents federal and state statutes and regulations and local policies and practices. Federal special education policy, as defined through the IDEA, is highly regulated. In part, this is because the federal statute is both a civil rights entitlement and an educational program. The procedures for providing education as well as the procedural safeguards afforded to parents are quite prescriptive.

The highly regulated special education practices and policies come into conflict with charter school laws designed to maximize autonomy and flexibility within schools (Ahearn et al., 2001; Rhim, Lange, Ahearn, \& McLaughlin, 2006). Our research has consistently documented frustration on the part of charter school policy makers and school operators with what they perceive as an overly narrow and rigid approach to providing special education, from the need to determine eligibility for services to providing individually tailored programs and services (Ahearn et al., 2001; McLaughlin \& Henderson, 1998).

\section{Parental Choice and Team Decision Making}

The foundation of special education is the principle of individualized educational decision making aimed at meeting the needs of an individual student with a disability. The IEP defines what is "appropriate" for a specific child, and the process for determining what is appropriate is expected to 
involve a team of professionals and the child's parent or guardian, who will reach consensus on the goals for the child, the special education and related services that will be provided to meet those goals, the settings in which the education will be delivered as well as by whom, and how the IEP will be determined to be effective. Decisions regarding what constitutes an appropriate education rest with the team that develops the IEP.

In practice, IEP teams vary markedly in terms of the balance of power in decision making between professionals and parents (Furney \& Salembier, 2000; Turnbull, Turnbull, Erwin, $\&$ Soodak, 2006). The IEP team can be influenced by organizational and/or resource constraints such as personnel or availability of certain programs. The IEP team may also hold certain philosophical or professional opinions regarding how best to educate children with disabilities. Thus, professionals on an IEP team may believe that a certain therapy or intervention is needed to help the child benefit from education.

In addition, members of the team may be committed to promoting inclusion or, alternatively, believe that a more specialized setting may be most appropriate for a specific child. Within the charter school philosophy, parental choice is central. Charter schools operate under the assumption that parents can and will act in the best interests of their child and should be able to freely make choices about where and how they wish to educate their child. Thus, if an individual charter school does not offer the type of program that is "appropriate" for a child, the parents will not elect to enroll their child in that program. This is in contrast to the notion of shared decision making required within special education, which imposes the obligation on the state and local education agencies to ensure the rights of the individual child with a disability notwithstanding the parent's right to choose (Ahearn et al., 2001).

This conflict between a parent's right to choose and the requirements imposed on the state can surface in the Child Find and eligibility evaluation procedures, which require that children suspected of having a disability be provided with a comprehensive assessment. Although parents must consent to have their child evaluated, schools initiate referrals to special education. Our research found that one of the reasons some parents seek to enroll their child in a charter school is to avoid identification for special education. Further, charter school administrators and teachers reported that parents of students with an identified disability do not always inform a charter school that their child has an IEP or received special education out of a desire to shed the label of special education when they enroll in the new school (Ahearn et al, 2001).

Another source of tension associated with implementing IDEA in charter schools is the concept that schools not only must make accommodations for a student with a disability but also may have to alter the characteristics of individual school curricula to provide the type or intensity of special education services specified on an IEP. Charter schools generally are small, mission-driven schools that offer a specific curriculum, or approach to learning, such as Montessori, Core Knowledge, or Expeditionary Learning Outward Bound (Nelson et al., 2000).

Many charter schools, by design, hold strong appeal for some students and little or no appeal for other students. Abiding by IDEA can force schools to deviate from their mission so as to meet individualized needs of a single student with a disability (Ahearn et al., 2001; Rhim \& McLaughlin, 2001). For instance, if the school is committed to philosophically serving all students in inclusive settings, it will have to modify its mission to accommodate a child who requires a more restrictive educational environment. Similarly, charter schools that are based on ungraded, selfdirected learning can be severely challenged by a child who may require more structure.

At the other end of the continuum, we documented concerns among state and local special education administrators and policy makers when parents chose segregated disabilityspecific schools such as schools for students with autism or schools for students with emotional and behavior disorders. They considered this to be in opposition philosophically to the principles of inclusion, which they believed deeply were in the best interests of students with disabilities (Rhim \& McLaughlin, 2001).

For charter school operators, understanding the procedures and negotiating the various legal requirements become paramount. For state and local special education administrators, the chief concerns are to be accountable for adhering to the IEP and to ensure that all eligible students are identified and served appropriately.

\section{Compliance Versus Autonomy}

A second policy tension between charter schools and IDEA is the emphasis on procedural compliance associated with special education and the principles of autonomy and regulatory flexibility that are central to the charter school concept. Charter schools vary considerably in the amount of freedom they have, but none is completely free from some regulation and oversight. At a minimum, they must adhere to state regulations regarding health and safety, fiscal management, and overall integrity of the educational program. Accountability in special education, as clearly prescribed in federal statutes, focuses on compliance with procedures and rules.

Our case studies and surveys provide some insight into the extent to which charter schools are being held accountable for the education of students with disabilities and reveals the inherent challenges associated with holding charter schools accountable. IDEA defines the parameters of special education accountability by assigning state education agencies the responsibility for implementing the provisions of the Act. Through the "general supervision" clause, states may delegate most of the responsibility for providing FAPE to local school districts. 
State charter laws give authorizers significant autonomy to determine how to hold their charter schools accountable for issues related to special education. The small percentage of states that actually dictate accountability measures for students with disabilities in their charter laws limit the accountability to general assurances not to discriminate and data regarding special education enrollment (Ahearn, Rhim, Lange, \& McLaughlin, 2005). Few charter authorizers incorporate any special education indicators in their evaluation of charter schools for renewal (Rhim, Lange, Ahearn, \& McLaughlin, 2007a).

Further complicating meaningful accountability is the reality that most charter schools share to some extent the responsibility for providing special education with their authorizer or a local school district. (Rhim, Lange, Ahearn, \& McLaughlin, 2006; 2007a; 2007b; Rhim, Ahearn, \& Lange, 2007). Shared responsibility may undermine accountability because multiple entities contribute to educational outcomes. Therefore, discerning who is to be held accountable for academic outcomes of children with disabilities in charter schools is difficult. For example, does "shared" mean that a charter school is responsible for all services and the district is responsible for supervising the delivery of services, or, alternatively, is the responsibility for specific services delegated between the school and the district? Then again, if the district retains the special education funds and provides direct services to students with disabilities enrolled in the charter school, who is legally responsible for aligning services with the charter schools curriculum and providing compensatory services if a student does not receive all the services outlined on his or her IEP? (Ahearn et al., 2001; McLaughlin \& Henderson, 1998; Rhim, Lange, Ahearn, \& McLaughlin, 2005; 2006; 2007a; 2007b)

The legal identity of a charter school becomes a critical factor in assigning accountability for students with disabilities. In our initial seven-state case studies we found that the charter school's legal identity, as an LEA or as a school, had major implications for how special education was interpreted and provided in schools. The charter schools that were operating special education programs as autonomous LEAs often had limited understanding of their responsibilities and how they shared responsibility with states and districts leaders. Charter operators did not know or resisted reporting requirements and other monitoring and compliance activities. The central issue was who "owned" the child with an IEP and who was responsible for providing FAPE (Rhim \& McLaughlin, 2001; Ahearn, Rhim, Lange, \& McLaughlin, 2005).

Related to the notion of legal identity is the linkage between an individual charter school and a traditional school district for the purpose of implementing IDEA. Project SEARCH revealed that state laws determine legal status, but separate from legal status is the link that charter schools form with a local district. Our research documented that charter schools fall along a continuum from no link to total link. A no-link charter school is its own LEA and has total responsibility for providing special education and related services. At the other end of the continuum, a total-link charter school is considered to be part of an LEA and the LEA retains responsibility for providing special education. In the middle are partial-link schools with either a required or a negotiated relationship between a charter school and its local district.

Linkage is important because, while legal identity defines legal responsibility, linkage captures the way that responsibilities for special education evaluation and services are fulfilled (Ahearn, Giovanetti, Lange, Rhim, \& Warren, 2004). For instance, a charter school that is legally autonomous may elect to link with a district to purchase special education services. Alternatively, a charter school that is legally part of a district may be able to negotiate with the local district to purchase services outside of the district. We found that contract negotiations between authorizers and charter school operators were essential to clearly define special education responsibilities for a school versus other entities (Ahearn et al, 2001). The link between a charter school and a local district's special education infrastructure defines most aspects of the charter school's responsibilities for special education.

\section{Practical Challenges}

Providing special education and related services to individual students with disabilities requires more than a clear understanding of legal responsibilities and procedures. Similar to traditional public schools, charter schools frequently struggle with practical challenges related to access, scarcity of adequate funding, and lack of capacity to provide services. Under these broader categories of challenges, charter schools also face some unique challenges associated with their governance structure, size, and novelty. All of these factors interfere with charter schools' capacity to provide FAPE and to address the requirements of LRE (Ahearn et al., 2001).

\section{Enrollment}

One of the earliest concerns about charter schools was that they would "cream" the best students and avoid accepting students who might be difficult to educate (Fuller \& Elmore, 1996; Wells, 1993). In particular, concerns were raised that students with special needs, such as those with disabilities, would not have the opportunity to enroll. In the area of access and enrollment, charter schools have been under the microscope (Guarino \& Chau, 2003; Fiore, Harwell, Blackorby, \& Finnigan, 2000; McLaughlin \& Henderson, 1998; Miron \& Nelson, 2002). Respondents to our survey of charter school authorizers reported that the percentage of the total student population identified as having a disability enrolled in charter schools granted by the authorizer ranged from $0 \%$ to $100 \%$, with a mean of $12.8 \%$. This 
percentage represents a weighted average. When the total number of students with disabilities is divided by the total enrollment reported by those authorizers who provided both figures $(31,414 / 369,604)$, the overall percentage of students with disabilities enrolled in the charter schools drops to $8.5 \%$. The difference reflects large variations in the number of students with disabilities enrolled in charter schools granted by the authorizers. In particular, three authorizers reported that they had authorized charter schools that focus on students with disabilities and reported that $100 \%$ of the students were identified as having a disability (Rhim, Lange, Ahearn, \& McLaughlin, 2007b).

Respondents to our survey of charter operators reported enrolling a total of 11,310 students with disabilities, with a mean of 33, a minimum of 0 , and a maximum of 466 students per school. Analyzed according to percentage of the total school population in our sample, students with disabilities comprised $10.57 \%$ of the population (i.e., 11,310 of 106,953 students). Analyzed as a percentage of total enrollments per school that reported both total student enrollment and special education enrollment, the mean percentage of students with disabilities was $13.14 \%$, with a minimum of $0 \%$ and a maximum of $100 \%$.

The difference between the percentage of the total sample population and the mean percentage per school is attributable to outliers (i.e., very large and very small schools and schools that reported $0 \%$ or $100 \%$ students with disabilities). When the schools that identified themselves as primarily for students with disabilities $(n=9)$ were removed from the analyses, the mean percentage of students with disabilities decreased to $11.2 \%$. According to the most recent data from the U.S. Department of Education (2003), students with disabilities represent $12.1 \%$ of the public school population nationwide.

The schools that participated in the Project Intersect survey of charter school operators reported enrolling a total of 1,302 students identified as having a severe disability, with a mean of 3.82 students per school. As a percentage of the total number of students with an IEP, $8.5 \%$ of those students were identified as having a severe disability, with percentages ranging from $0 \%$ to $100 \%$ (Rhim, Lange, Ahearn, \& McLaughlin, 2007b).

Finally, our examination of enrollments in California charter schools found that students with disabilities are opting to enroll in charter schools, but when grouped by type of disability, the proportions of students enrolling differ notably. In particular, charter schools educated more students with specific learning disabilities (61\% compared to $55 \%)$ and fewer students with mental retardation (2\% compared to 6\%). Possibly in part because of this enrollment pattern, charter schools served more students with disabilities in general education classrooms $80 \%-100 \%$ of the day ( $71 \%$ compared to $50 \%$ ) and fewer students in the classroom $40 \%-79 \%$ of the day ( $11 \%$ compared to $22 \%$ ).
Although charter schools enrolled children characterized as having low-incidence disabilities who frequently require more intensive services (i.e., deaf-blind, traumatic brain injury, hard-of-hearing, deaf, visual impairment, orthopedic impairment, and multiple disabilities), charter schools did not educate as many students in what are characterized as more restrictive settings (i.e., homebound/hospital, residential public or private, separate day private, correctional facilities, or private school placements made by parents) (Rhim, Faukner, \& McLaughlin, 2006). Whether this finding reflects a change in the environment where students are receiving their special education services or whether charter schools are attracting more students who can succeed in the general education classroom environment is unclear. Further, these findings do not provide material insight into whether students with disabilities are receiving support services adequate to succeed in the general education classroom (Rhim, Faukner, \& McLaughlin, 2006).

In summary, contrary to early concerns that charter schools would exclude students with disabilities; multiple research studies have documented that charter schools are enrolling students with disabilities and, in some cases, attracting more students with disabilities than traditional public schools. Additional research examining enrollment trends is required, however, before definitive conclusions can be reached regarding the extent to which charter schools are a viable option for students with a wide range of disabilities.

\section{Special Education Funding}

Funding special education in charter schools is a complex and frequently controversial matter (Nelson et al., 2000; Speakman \& Hassel, 2005). The most common complaint of charter operators is that they do not receive adequate funds to provide special education services. Lack of funding for special education is not unique to charter schools, but charter schools are doubly challenged because of their infancy and small size. As new schools, they must develop entire educational programs, whereas traditional public schools can draw upon established organizational systems and experienced personnel. Further, analogous to the challenges typically experienced by rural school districts, charter schools do not benefit from economies of scale in hiring specialized personnel or equipment.

Another issue involves the way in which federal (and state) special education funds are allocated to individual charter schools. Local districts pay for the cost of special education using a combination of federal, state, and local funds (Parrish, Harr, Anthony, Merickel, \& Esra, 2003). Part B of IDEA (2004) provides an allocation of federal funds for each state based on a standard formula, and these dollars flow through the state to local districts. States also fund special education using one of several formulas. Local districts are responsible for all remaining costs associated with providing special education. 
State charter school laws are typically silent regarding special education funding, with the possible exception of specifying that that charter schools must receive their "proportionate" or "commensurate" share of special education dollars (Ahearn et al., 2005). In their study of California charter schools, Guarino and Chau (2003) found that many charter schools do not access their federal or state special education funds because of "lack of information and capacity to study various options" (p. 173). How special education dollars actually flow to support students with disabilities who attend charter schools differs from state to state, as well as within a state.

Our school-level survey (Rhim, Lange, Ahearn, \& McLaughlin, 2007b) found that federal and state special education dollars are distributed in multiple ways to charter schools. In $35 \%$ of the sample schools, federal and state special education funds go directly to the charter school. Approximately $20 \%$ of the respondents reported that both federal and state special education dollars flow to the district, which retains the funds and provides charter schools with relevant special education services. Roughly $15 \%$ of the respondents reported that federal and state special education funds go through the local district to the charter, with the district retaining a set percentage. Between $7 \%$ and $8 \%$ of the respondents reported that all federal and state special education funds go through the local district to the charter, with the charter receiving the full allocation. Approximately a quarter of the operators did not report how federal or state special education dollars flowed to them or reported that they flow an "other" route. For the schools that reported that their district retains a specific percentage of their federal and state special education dollars, the mean percentage retained was approximately $20 \%$, but the amount ranged from $2 \%$ to $100 \%$.

Presumably, schools that receive their federal and state special education dollars directly are able to exercise a greater degree of control over how the dollars are allocated to educate students with disabilities and perhaps better ensure that these services align with the school's broader mission. For instance, schools that control their special education dollars presumably have control over their staff and special education service delivery. This is in contrast to charter schools that do not have control of their special education dollars and consequently may be subject to the district's standard operating procedures, which may or may not align with the school's unique mission.

\section{Special Education and Related Services}

Providing special education and related services requires that charter schools understand their responsibilities and have the resources to pay for these services and also that they have the capacity to provide the services required. Our initial case studies and subsequent surveys documented that charter schools frequently struggle to amass the capacity required to provide special education and related services. Further, lack of staff and lack of history in providing special education compound the challenges (Ahearn et al., 2001). The result is that children with IEPs may not be provided what is considered an appropriate education by an IEP team but, instead, what is available at a school.

In a very early study of charter schools in Colorado, McLaughlin and Henderson (1998) documented the problems that operators faced in recruiting and hiring qualified special education teachers. Based on their comprehensive analysis of Michigan charter schools, Miron and Nelson (2002) found that charter schools were struggling to provide special education and related services, which they attributed to inexperienced teachers and administrators, lack of established policies and procedures, too few dollars dedicated to instruction of special populations, and a shortage of certified special education teachers. Analyzing the charter movement in multiple states, Finn, Manno, and Vanourek (2000) found that "some charter schools do not meet all their students' special needs" but attributed the shortcoming not to discrimination but, rather, to "lack of experience, expertise, or resources" (p. 159).

Our research found that state and local district administrators and charter school personnel had concerns about the quality of special education services that students with disabilities were receiving in charter schools (Ahearn et al., 2001; McLaughlin \& Henderson, 1998; Rhim, Lange, Ahearn, \& McLaughlin, 2006). In some instances, charter schools reduce students' specialized services such as speech and occupational therapy because of the lack of adequate personnel. In other cases, a child may have received all of his or her education in the general education classroom with only consultative services or tutoring after hours because not enough children were attending the school to generate the resources to hire more special education personnel. In fact, charter operators reported that the inability to realize "economies of scale" can limit their ability to provide adequate services (Ahearn et al., 2001).

Our analyses of special education and related services documented that during the 2003-04 school year, charter schools in California provided a variety of services to students with disabilities. Notably more students in these schools than in traditional public schools in California were provided individual and small-group instruction $(9.1 \%$ vs. $1.56 \%)$, assistive technology $(5.72 \%$ vs. $1.16 \%)$, and resource specialist services ( $56.15 \%$ vs. $45.86 \%$ ). Conversely, charter schools were providing fewer special day classes $(14.96 \%$ vs. $28.01 \%)$ and language and speech $(31.54 \%$ vs. $36.86 \%$ ) services. Our findings regarding assistive technology may be skewed by data from the independent-study charter schools (e.g., cyber/virtual schools) that rely on computer technology to deliver their curricula. Although these schools may be providing assistive technology through the use of computers, computers in and of themselves do not 
necessarily constitute assistive technology specific to the needs of students with disabilities.

One clear finding from our research (Ahearn et al., 2001; Rhim, Lange, Ahearn, \& McLaughlin, 2006) is that charter schools benefit from affiliation with a special education "infrastructure" that supports the provision of special education and related services in individual schools. A special education infrastructure can be a local district or an intermediate administrative unit. But charter schools have also formed cooperatives or contracted with a community-based nonprofit, a comprehensive education service provider, or some other entity to help them provide special education. Some of these entities provide all special education services, including all administrative and legal services, and others serve primarily as an agent to identify service providers. These infrastructures allow individual charter schools to pool their resources and buy services or expertise that would otherwise be virtually impossible to amass in a single school.

Thus, while charter schools strive to establish themselves as autonomous entities, special education is one area in which it may not be in their best interests-or their students' - to operate in isolation. To build their capacity to meet their obligations under IDEA, charter schools must either build internal systems and structures that almost parallel those of school districts or must affiliate with an external infrastructure that can provide the school with the necessary expertise.

The findings from our research point to the critical need for extensive and focused technical assistance to build the capacity of charter school operators and authorizers relative to special education. The lack of knowledge and experience, particularly among new charter operators, is a serious problem. Charter operators typically resist efforts to mandate training or specific levels of knowledge, however, because they tend to oppose regulation and bureaucracy. State education agencies and state charter organizations are beginning to require more "up-front" training and also are providing extensive technical assistance through training during the application phase and once groups are granted their charters (Rhim, 2006; Rhim et al., 2007a; 2007b).

Our surveys of authorizers and operators have documented the growing technical assistance and training network (Rhim et al., 2007a; 2007b). Some authorizers are requiring technical assistance and training for potential operators and charter boards prior to granting charters. Yet, offering assistance on a voluntary basis to schools after they have been granted their charter is a more common approach. Charter schools are also benefiting from existing public school support networks (i.e., state departments of education, local districts, and intermediate units) and charterspecific networks (e.g., charter resource centers, charter associations, special education cooperatives) that provide training incorporating the unique characteristics of charter schools. More than $90 \%$ of the charter school operators identified local nonprofits, charter school resource centers, charter school associations, and individual consultants as sources of specialized special education technical assistance.

\section{Charter Schools and LRE}

A recurrent finding in the charter school research is the prevalence of educating all children with disabilities in "inclusive" classrooms. The Fiore et al. (2000) study found that most charter schools reported serving children with disabilities in inclusive classrooms. How the schools defined "inclusion," however, was not clear. Guarino and Chau (2003) found that, relative to traditional public schools, charter schools served a higher percentage of their students with disabilities in inclusive general education classrooms.

Similar to the Fiore et al. study, however, how charter schools define the notion of inclusion beyond simple placement in a general education classroom is unclear. Several of our studies also documented the high rates of "inclusion" in charter schools. (McLaughlin \& Henderson, 1998; Ahearn et al., 2001; Rhim, Faukner, \& McLaughlin, 2006). But our research did not permit us to verify or examine the meaning of the term "inclusion" in the charter sector. Anecdotal evidence raised questions about the extent to which inclusion represented placement in a general education classroom or the actual provision of appropriate supports to enable a student with a disability to succeed in the general education classroom.

Our California research documented notable differences in the educational placements of students in charter schools. The 270 charter schools we examined reported that they educate $71 \%$ of their students in general classrooms $80 \%-100 \%$ of the day, whereas traditional public schools educate $49.6 \%$ of their students with disabilities in this setting. Charter schools educate $10.6 \%$ of their students in general classrooms $60 \%-79 \%$ of the time, whereas traditional public schools serve $22 \%$ of their students with disabilities in this setting. And charter schools educate $15.8 \%$ of their students in the general education classroom less than $60 \%$ of the day, whereas traditional public schools educate $24.1 \%$ of their students with disabilities in this setting (Rhim, Faukner, \& McLaughlin, 2006).

The use of more inclusive settings has several possible explanations. One, which we noted above, is the lack of adequate staff and resources to provide more specialized instruction or therapies during the school day. Also, because charter schools are typically smaller than the average traditional public schools, it is likely neither economically nor educationally feasible to create special classes or other settings for only a few students. The use of more inclusive settings may indicate that charter schools are rethinking delivery of special education and related services and making a concerted effort to provide students with disabilities access to the general education classrooms and curriculum. On the 
one hand, students who are enrolling in charter schools may require less intensive special education or the supports that require more restricted settings. On the other hand, whether because of resources, lack of experience, or philosophy, charter schools possibly are adopting a "schoolwide" model of special education that does not necessarily address the individual needs of specific students with disabilities.

\section{Outcomes for Students with Disabilities}

Data on academic outcomes for students with disabilities enrolled in charter schools are limited. In large part, this is because most charter schools are small. For many schools, assessment results for the sub-group of students with disabilities, which is usually quite small, are not reported publicly because of state confidentiality rules. Consequently, it is not possible to examine outcomes based on publicly released data.

In partnership with the California Department of Education, we conducted a large study in California that captured academic outcomes for students with disabilities. Based on the availability of data, we examined the academic outcomes on the state achievement test in spring 2004 for all 270 charter schools for which the state had data (Rhim, Faukner, \& McLaughlin, 2006). We examined the academic proficiency rate of students with disabilities enrolled in the 270 charter schools and compared this to the rate for students with similar disabilities enrolled in traditional public schools. ${ }^{1}$ We analyzed performance on the English and mathematics California Standard Test (CST) for all students with disabilities statewide and for specific subgroups of students with disabilities.

Regardless of the type of school, few children with disabilities attain proficiency in either English or mathematics on the CSTs. In aggregate, students with disabilities enrolled in charter schools posted higher proficiency rates (i.e., students who achieve proficient or above) in Englishlanguage arts than their peers in traditional public schools (13.74\% compared to $9.96 \%$ scoring at the proficient or advanced levels) in the spring 2004. In mathematics, students with disabilities enrolled in charter schools also posted

\footnotetext{
Most research examining outcomes aims to determine whether there is a statistical significance between two distinct samples of a population. In our case, the populations consist of students with disabilities enrolled in charter schools compared to their peers in traditional public schools. We did not draw a sample, though. Rather, we compared the total population of students with disabilities in charter schools for which the state maintained data and compared their outcomes to the total population of their peers in traditional public schools. Because we are not trying to generalize to the population from a sample of the population, the notion of statistical significance cannot be applied to our data. Any differences found between two distinct populations would be considered significant by definition, because they would actually exist within these populations. Of interest to us were differences related to special education between the two types of schools, and whether any such differences were large enough to be considered noteworthy or practically significant.
}

higher proficiency rates, but the difference was relatively small (14.40\% compared to $13.22 \%$ ) (Rhim, Faukner, \& McLaughlin, 2006).

In addition to comparing the aggregate data, we analyzed the performance data according to students' gender, grade level, English language learner status, ethnicity, and prevalent disability categories. When examined according to these specific subcategories, the students with disabilities enrolled in charter schools achieved higher proficiency rates on the English-language arts CST than students in traditional public schools did in 16 of the 19 subgroup categories. In some instances, the difference was notably large (i.e., $9 \%$ or greater for emotional disturbance, other health impairment, and autism). Reliability of this finding may be limited, however, because of the disparity in sample size between traditional and charter school students with these disabilities (Rhim, Faukner, \& McLaughlin, 2006).

Another notable difference in proficiency rates among the larger subcategories included higher rates for charter school students enrolled in middle schools (13.82\% proficient compared to $7.47 \%$ proficient in the traditional schools), charter students with speech and language impairments (30.72\% proficient compared to $25.62 \%$ ), and charter students who were white (23.78\% proficient compared to $18.68 \%$ ).

Our analyses of mathematics proficiency levels by subgroups revealed fewer material differences between the performance of students with disabilities in charter schools and in traditional public schools. More students with disabilities enrolled in charter schools demonstrated proficiency than their peers in traditional schools in 14 of the 19 categories, but for most the subgroups, the differences were relatively small (i.e. $3 \%$ or less). Exceptions to this finding were the performance of students with autism who enrolled in charter schools (38.60\% proficient compared to $32.29 \%$ ) and pacific islanders $(28.47 \%$ versus $9.98 \%)$. As noted previously, however, the number of these students enrolled in charter schools raises questions about reliability of these differences (Rhim, Faukner, \& McLaughlin, 2006).

Our findings related to the proficiency levels of students with disabilities enrolled in California charter schools do not provide insight regarding cause, and we could not discern whether the performance data reflect a higher initial baseline performance level or greater academic gains associated with instruction in charter schools. Rather, the data raise additional questions that require more research. Nevertheless, given that prior research has documented that students in charter schools in California scored the same as or below their peers in traditional public schools (Zimmer et al., 2003), the higher levels of proficiency that we documented for students with disabilities in charter schools in California relative to their peers in traditional public schools raises additional questions worth further investigation. For instance, are charter schools simply attracting higher performing students with 
disabilities? Alternatively, are charter schools providing students with disabilities better opportunities to achieve greater levels of proficiency?

To determine the relative effects of charter schools on the academic performance of students with disabilities, we have to examine individual student growth or change in achievement over time. The use of growth models that measure change in performance within schools should allow states to track more precisely the achievement levels of students with disabilities who enroll in charter schools, as well as examine the performance of charter schools compared to traditional public schools. Other potentially informative outcome measures are school mobility and dropout rates, as well as graduation rates.

\section{CONCLUSION}

Charter schools represent an opportunity to create new public schools that, in theory, are responsive to individual students' and parents' specific educational goals and preferences. In theory, these goals align with the historic goals of IDEA. Yet, receiving a charter is not an end in itself. It simply grants the authority to begin the hard work of starting and operating a new public school. Once granted a legally binding charter, its founders are charged with granting access and providing adequate services to all students, including students with disabilities. Providing equal opportunities to students with disabilities is one of multiple indicators of the extent to which these new schools are fulfilling their public mission. Given the complexities of special education, charter schools have to understand their responsibilities associated with relevant federal and state statutes and then acquire the capacity to fulfill these responsibilities. In turn, charter school authorizers must ensure that they can hold charter schools accountable for the academic progress of all students.

Through our multiple research studies, we have sought to identify and examine the key issues and opportunities emerging at the intersection of state charter school statutes and federal special education statutes. Our case studies revealed the key issues, and our surveys of key stakeholders verified and quantified the strategies and organizations that charter schools are using to build their classroom-level and organizational capacity. The available data about educating students with disabilities in the charter sector are relatively limited because of both the scope and the quantity of research that has been conducted on the issue. The research that has been conducted has examined new opportunities that charter schools can potentially offer to students with and without disabilities. At the same time, these new schools may struggle to understand their responsibilities related to students with disabilities, to enroll their proportionate share of students with disabilities, and to provide required services.
In addition, charter schools struggle with the same issues as traditional public schools (e.g., lack of resources, shortage of special education staff, and implementation of requirements associated with NCLB), and they also face unique challenges associated with policy ambiguity, their status as schools of choice, and their lack of both experience and resources.

Tensions related to providing special education and related services to students with disabilities who choose to enroll in charter schools require careful consideration. But they do not necessarily have to be a barrier to students with disabilities' obtaining a high-quality education. Charter schools must be aware of the scope of their responsibility to educate students with disabilities and to develop the capacity to provide appropriate services and supports. Furthermore, although charter schools face challenges associated with developing new systems from scratch, this process provides administrators and teachers the opportunity to create special education programs that ideally will reflect best practices rather than decades of standard practice, and to ensure that special education is integrated into the general education program and is not merely an afterthought.

\section{REFERENCES}

Ahearn, E., Giovannetti, E. A., Lange, C. M., Rhim, L. S., \& Warren, S. H (2004). Primer for charter school authorizers: Special education requirements and including students with disabilities in charter schools. Alexandria, VA: National Association of State Directors of Special Education.

Ahearn, E., Lange, C., McLaughlin, M. J., \& Rhim, L. M. (2001). Project SEARCH: Special education as requirements in charter schools. Final report of a research study. Alexandria, VA: National Association of State Directors of Special Education.

Ahearn, E. A., Rhim, L. M., Lange, C., \& McLaughlin, M. (2005) Project Intersect research report \#1: State legislative review. College Park: University of Maryland, Project Intersect.

Americans with Disabilities Act, 42 U.S.C. $\S 12101$ et seq.

Anderson, L., Edelman, N., Cotton, L., Finnigan, K., Donnelly, M. B., \& Price, T. (2002). A decade of charter schools: Evaluation of the public charter schools program: 2000-2001 evaluation report. Retrieved March 1, 2005, from http://sri.com/policy/cep/choice/yr2.pdf

California Department of Education. (2007a). California Charter School Facts. Retrieved March 17, 2007 from http://www.cde.ca.gov/sp/cs/re/ csfactsapr04.asp

California Department of Education. (2007b). California Charter School Facts. Retrieved March 17, 2007 from http://datal.cde.ca.gov/data quest/OthEnrPg2.asp

Carnoy, M., Jacobsen, R., Mishel, L., \& Rothstein, R. (2000). The charter school dust-up: Examining the evidence on enrollment and achievement. New York City: Teachers College Press.

Center for Education Reform. (2007). Charter school. Retrieved June 6 , 2007 from http://www.edreform.com/index.cfm?fuseAction=stateStatChart\&psectionid $=15 \& \mathrm{cSectionID}=44$

Chubb, J. E., \& Moe, T. M. (1990). Politics, markets and America's schools. Washington, DC: Brookings Institution.

Finn, C. E., Manno, B. V., \& Vanourek, G. (2000). Charter schools in action: Renewing public education. Princeton, NJ: Princeton Press.

Finnigan, K., Adelman, N., Anderson, L., Cotton, L., Donnelly, M., \& Price, T. (2004). Evaluation of the public charter school program: Final report. Washington, DC: SRI International. 
Fiore, T. A., Harwell, L. A., Blackorby, J., \& Finnigan, L. A. (2000). Charter schools and students with disabilities: A national study. Washington, DC: U.S. Department of Education, Office of Educational Research and Improvement.

Fuller, B., \& Elmore, R. F. (1996). Who chooses? Who loses? Culture, institutions and the unequal effects of school choice. New York: Teachers College Press.

Furney, K. S., \& Salembier, G. (2000). Rhetoric and reality: A review of the literature on parent and student participation in the IEP and transition planning process. In D. R. Johnson \& E. J. Emanuel (Eds.), Issues influencing the future of transition programs and services in the United States. (pp.111-126). Minneapolis: University of Minnesota, National Transition Network.

Giovannetti, E., Ahearn, E., \& Lange, C. (2001) Charter schools and the education of students with disabilities. Alexandria, VA: National Association of State Directors of Special Education.

Guarino, C., \& Chau, D. (2003). Special education in charter and conventional public schools. In R. Zimmer, R. Buddin, D. Chau, G. Daley, D. Guarino, L. Hamilton, et al. (Eds.), Charter school operations and performance: Evidence from California. (pp. 161-173). Santa Monica, CA: RAND.

Heubert, J. P. (1997). Schools without rules? Charter schools, federal disability law, and the paradoxes of deregulation. Harvard Civil RightsCivil Liberties Law Review, 32, 301-353.

Hill, P., Lake, R., \& Celio, M. B. (2002). Charter schools and accountability in public education. Washington, DC: Brookings Institution.

Individuals with Disabilities Education Act of 1997, 105-17, 611 et seq.

Individuals with Disabilities Education Improvement Act of 2004, U.S Code Title 20, Chapter 33-Education of Individuals with Disabilities, as amended by P. L. 108-466.

Individuals with Disabilities Education Improvement Act, 20 U.S.C. §1413 (2004).

Kolderie, T. (1990). Beyond choice to new public schools: Withdrawing the exclusive franchise in public education. Washington, DC: Progressive Policy Institute.

Lake, R. J., \& Hill, P. T. (2006). Hopes, fears and reality: A balanced look at American charter schools in 2006. Seattle: National Charter School Research Project Center on Reinventing Public Education.

Lange, C., Rhim, L. M., Ahearn, E., \& McLaughlin, M. (2005). Project Intersect research report \#2: Survey of state directors of special education. College Park: University of Maryland, Project Intersect.

Lubienski, C. (2004). Charter school innovation in theory and practice: Autonomy, R \& D, and curricular conformity. In K. Bulkley \& P. Wohlstetter (Eds.), Taking account of charter schools: What's happened and what's next? (pp. 72-92). New York: Teachers' College Press.

Maryland Public Charter School Act of 2003. (SB 75, Chapter 358 of 2003 Laws of Maryland). Section 9-101, et seq., of the Education Article, Annotated Code of Maryland.

Maryland State Department of Education (2007). Maryland Charter School Program. Retrieved 3/17/07 from http://www.marylandpublicschools. org/MSDE/programs/charter_schools/

McLaughlin, M. J., \& Henderson, K. (1998). Charter schools in Colorado and their response to the education of students with disabilities. Journal of Special Education, 32(2), 99-107.

Miron, G., \& Nelson, C. (2002). What's public about charter schools: Lessons learned about choice and accountability. Thousand Oaks, CA: Corwin.

Nathan, J. (1996). Charter schools: Creating hope and opportunity for American education. San Francisco: Jossey-Bass.

National Association of Charter School Authorizers. (2005). Principles and standards for quality charter school authorizing. Retrieved March 1, 2005, from http://www.nationalcharterschools.org/uploads/pdf/re source_20040604082641_Quality\%20Authorizing.pdf
Nelson, B., Berman, P., Ericson, J., Kamprath, N., Perry, R., Silverman, D., et al. (2000). The state of charter schools: Fourth year report. Washington, DC: U.S. Department of Education, Office of Education Research and Improvement.

No Child Left Behind Act of 2001, 20 U.S.C.A. § 6301-6578 (West 2002).

Palmer, L. B., \& Gau, R. (2003). Charter school authorizing: Are states making the grade? Washington, DC: Thomas B. Fordham Foundation.

Parrish, T., Harr, J., Anthony, J., Merickel, A., \& Esra, P. (2003). State special education finance systems, 1999-2000-Part I. Palo Alto, CA: American Institutes for Research. Retrieved March 17, 2007 from http://www.csef-air.org/

Rhim, L. M (2006). An evaluation of the Maryland state charter school program. Baltimore: Maryland State Department of Education.

Rhim, L. M., Ahearn, E., \& Lange, C. (2007). Charter school statutes and special education: Policy answers or policy ambiguity? Journal of Special Education 41(1), p. 50-63.

Rhim, L. M., Faukner, J., \& McLaughlin, M. J. (2006). Research report \#5: Access and accountability for students with disabilities in California charter schools. College Park: University of Maryland, Center for the Study of Exceptional Children and Youth.

Rhim, L. M., Lange, C., Ahearn, E., \& McLaughlin, M. J. (2005). Project Intersect research report \#3: Survey of state charter school officials. College Park: University of Maryland.

Rhim, L. M., Lange, C., Ahearn. E., \& McLaughlin, M. J. (2006). Project Intersect research report \#4: Charter school special education infrastructures. College Park, MD: University of Maryland, Project Intersect.

Rhim, L. M., Lange, C., Ahearn, E., \& McLaughlin, M. J. (2007a). Project Intersect research report \#6: Survey of charter school authorizers. College Park: University of Maryland, Project Intersect.

Rhim, L. M., Lange, C., Ahearn, E., \& McLaughlin, M. J. (2007b). Project Intersect research report \#7: Survey of charter school operators. College Park: University of Maryland, Project Intersect.

Rhim, L. M., \& McLaughlin, M. J. (2001). Special education in American charter schools: State level policy, practices and tensions. Cambridge Journal of Education, 31(3), 373-383.

Smith, N. (2005). Square pegs: Charter school authorizers in non-charter agencies (Issue Brief 7). Alexandria, VA: National Association of Charter School Authorizers.

Speakman, S., \& Hassel, B. C. (2005). Charter school funding: Inequities new frontier. Retrieved March 17, 2007 from http://www.edexcel lence.net/institute/charterfinance/

Sugarman, S. D., \& Kuboyama, E. M. (2001). Approving charter schools: The gate-keeper function. Administrative Law Review, 53(3), 860-942.

Turnbull, A. P., Turnbull, H. R., Erwin, E., \& Soodak, L. (2006). Families, professionals, and exceptionality: Positive outcomes through partnerships and trust (5th ed.). Upper Saddle River, NJ: Merrill/Prentice Hall.

U.S. Department of Education. (2003). Twenty-fourth annual report to Congress on the implementation of the Individuals with Disabilities Education Act. Washington, DC: U.S. Government Printing Office. Retrieved February 5, 2006, from http://www.ed.gov/about/offices/list/ osers/osep/research.html

U.S. Department of Education. (2007). Charter Schools Program: Funding status. Retrieved February 1, 2007 from http://www.ed.gov/programs/ charter/funding.html

Wells, A. S. (1993). Time to choose: America at the crossroads of school choice policy. New York: Hill and Wang.

Zimmer, R., Buddin, R., Chau, R., Daley, G., Guarino, D., Hamilton, L., et al. (Eds.). (2003). Charter school operations and performance: Evidence from California. Santa Monica, CA: Rand. 